\title{
Season and sediment nutrient additions affect root architecture in the temperate seagrasses Posidonia australis and $P$. sinuosa
}

\author{
Renae K. Hovey*, Marion L. Cambridge, Gary A. Kendrick \\ School of Plant Biology and The UWA Oceans Institute, The University of Western Australia, Crawley, WA 6009, Australia
}

\begin{abstract}
We examined the root systems of 2 temperate seagrasses, Posidonia australis and $P$. sinuosa, testing the effects of nutrients and season on root architecture. Transplants of each species were grown in pots containing a standardised sand medium and a localised supply of nitrogen $(\mathrm{N})$, phosphorus (P), or N and P combined. P. australis and P. sinuosa showed similar root architecture (primary roots with numerous second-order laterals and few higher-order laterals), but $P$. australis produced a larger root system with longer laterals making up the bulk of root length. Seagrass with combined $\mathrm{N}$ and $\mathrm{P}$ produced a higher lateral root density (330 \pm 18 [SE] branches $\mathrm{m}^{-1}$ root compared to controls with $250 \pm 22$ ), and a lower topological index (TI: $0.72 \pm 0.03$ compared to controls with $0.84 \pm 0.02$ ). Despite this response in root architecture, there was no significant change in traits associated with absorptive capacity. Separate nutrient additions had little effect on roots. Root architecture was more complex in summer for both species, with more higher-order laterals (TI: $0.73 \pm 0.02$ ) resulting in a more dichotomous pattern compared to winter (TI: $0.86 \pm$ 0.01). $P$. australis had twice the root length and higher specific root length in summer than winter, mostly due to increases in lateral root number and length. This study demonstrated that $P$. australis and $P$. sinuosa display architectural and morphological plasticity with season and to a lesser extent nutrient addition. The complex root architecture in the slow-growing temperate Posidonia species may reflect hydrodynamic exposure and the importance for anchorage in wave-swept environments.
\end{abstract}

KEY WORDS: Posidonia · Nitrogen · Phosphorus · Root morphology · Seagrass · Topological index

\section{INTRODUCTION}

In most natural habitats, nutrient availability is unevenly distributed in space and time, and often limits plant growth. As a result, there is considerable research interest in the acquisition of nutrients by plant roots. Nutrient capture and carbon cost for nutrient uptake can be related to the architecture (spatial configuration) and morphology of roots (Lynch 1995). It has been proposed that plasticity in these traits allows plants to respond and take advantage of the unevenly distributed nutrients (Lynch 1995, Hodge 2004).
One response of a plant to access nutrients more efficiently is to alter the morphological properties of its roots, such as increasing root length and number of thin laterals, to increase the total absorptive area of the roots. Thinner lateral roots have more length per unit mass than thicker primary roots, and thus have greater nutrient uptake per unit root mass. Often associated with this change is the increase in specific root length (SRL: length per unit dry weight) due to the increased proportion of thinner roots (Yano \& Kume 2005). Plant roots encountering a nutrient-rich patch generally alter their architec- 
ture from a 'herringbone' root system to a more dichotomous or highly branched root system (Fitter et al. 1991, Robinson 1994, Hodge 2004). Herringbone branching patterns can be described as a main axis with side branches but few or no further orders of branching. This type of root system is commonly found in nutrient-poor sediments, as it is more efficient in exploiting sediment nutrients but at a higher cost of constructing thicker roots (Fitter \& Stickland 1991, Fitter et al. 1991). In contrast, dichotomous root systems are often indicative of sediments with nutrient-rich patches where a high number of branches increases the acquisition of available nutrients (Fitter 1991, Fitter \& Stickland 1991).

While there has been progress in observing, quantifying and interpreting root architecture and morphology in many terrestrial plant species, attempts at investigating roots in submerged aquatic plants like seagrasses has been limited (e.g. Kiswara et al. 2009). Similar to terrestrial grasses, seagrasses form extensive meadows via a network of underground rhizomes, but do so fully submerged in seawater. They are found globally (except in Antarctica) in shallow coastal waters (range 0.7 to 90 m water depth; Duarte 1991) and colonise a wide range of substrates from fine-muddy sediments to coral rubble, with a few taxa being able to grow on rock substrates. Roots of these aquatic plants possess many of the functional characteristics of land plants but are generally reduced in size and structure (Bristow 1975). After decades of debate as to whether seagrass roots are functional in nutrient acquisition or serve only to anchor the plants (Agami \& Waisel 1986), there is now evidence for the importance of roots in acquiring nutrients for a number of seagrass species (Evrard et al. 2005, Kilminster et al. 2006, Vonk et al. 2008). However, few studies have examined seagrass root systems beyond describing root architecture or estimating increases in root biomass over time (Marbà \& Duarte 2001, Balestri \& Lardicci 2006, Kiswara et al. 2009). Small or faster-growing species are usually the subject of study (e.g. Perez et al. 1994), but these show far more rapid or plastic responses than large species with inherently low growth rates. Sampling root biomass indicates whole-plant responses to nutrient status; e.g. root:shoot ratios are usually lower when nutrient availability is high but do not provide an understanding of finer details of differences within the root system when nutrients are localised in small patches in an overall lownutrient matrix.
A recent study on 6 tropical seagrass species showed that all of their root systems had herringbone branching patterns that varied little between sites of different sediment types and nutrient availability (Kiswara et al. 2009). This invariant response to nutrient availability has been demonstrated in terrestrial grasses and is suggested to be related to the difference between cost and benefit in grasses compared to dicotyledons, possibly due to less discrimination between position in the root system and root diameter (Fitter \& Stickland 1991, Taub \& Goldberg 1996). Essentially, this means that the higher construction cost of herringbone root systems cannot be assumed for grasses. While the effect of background nutrient availability and nutrient addition on seagrass root biomass has been investigated, the extent to which root architecture responds to localised nutrient supply remains unknown.

In this study, we examined the root response of 2 closely related temperate seagrass species, Posidonia australis Hook. f. and P. sinuosa Cambridge et Kuo, to localised nutrient supply (nitrogen and phosphorus, both alone and in combination) over 2 different seasons. These Posidonia species are longlived and slow-growing seagrasses that form persistent meadows throughout temperate Australia. This coastline is characterised by large, regular swell waves and low water column and sediment nutrient concentrations, unlike most seagrass habitats globally. Specifically, we focused on responses in root architecture (i.e. branching patterns) and morphology (i.e. root length, SRL and root surface area) for newly developed root systems in $P$. australis and $P$. sinuosa transplants. Measurements were made over 2 experiments of 6 mo duration, one during the active growing season (spring to summer), and the other during the season of slower growth (autumn to winter).

\section{MATERIALS AND METHODS}

\section{Study location}

The study was situated in Oyster Harbour, a sheltered estuary in southern Western Australia (35 $02^{\prime} \mathrm{S}$, $\left.117^{\circ} 56^{\prime} \mathrm{E}\right)$. Transplants were located adjacent to sites of earlier experiments (Bastyan \& Cambridge 2008, Cambridge \& Kendrick 2009) on a subtidal sand area on the south-eastern margin, in approximately $1.2 \mathrm{~m}$ water depth with a mean tidal range of $0.5 \mathrm{~m}$. Environmental characteristics are summarised in Table 1. 
Table 1. Environmental characteristics of the study site in Oyster Harbour, Western Australia, adapted from Hovey et al. (2011). Mean concentrations of $\mathrm{NH}_{4}$ and $\mathrm{PO}_{4}$ were measured in porewater sampled from pots during the mid-point of the winter experiment (mean $\pm \mathrm{SE}, \mathrm{n}=4$ )

\begin{tabular}{|c|c|}
\hline Characteristic & Value \\
\hline Water depth (datum) (m) & $1.2(0.87)$ \\
\hline Mean water temperature $(\max -\min )\left({ }^{\circ} \mathrm{C}\right)$ & $12-23(8-28)$ \\
\hline Daily photon flux density $\left(\mathrm{mol} \mathrm{m}^{-2} \mathrm{~d}^{-1}\right)$ & $5-15$ \\
\hline \multicolumn{2}{|l|}{ Water column nutrients $\left(\mu \mathrm{g}^{-1}\right)$} \\
\hline $\mathrm{NH}_{4}$ & $3-10$ \\
\hline $\mathrm{NO}_{3}$ & $4-5$ \\
\hline $\mathrm{PO}_{4}$ & $4-6$ \\
\hline \multicolumn{2}{|l|}{ Sediment porewater nutrients $\left(\mu g \mathrm{l}^{-1}\right)$} \\
\hline $\mathrm{NH}_{4}$ & $100-600$ \\
\hline $\mathrm{NO}_{3}$ & $2-30$ \\
\hline $\mathrm{PO}_{4}$ & $20-100$ \\
\hline \multicolumn{2}{|l|}{ Treatment porewater nutrients $\left(\mu \mathrm{g}^{-1}\right)$} \\
\hline \multicolumn{2}{|l|}{ Control } \\
\hline $\mathrm{NH}_{4}$ & $276.2 \pm 10.5$ \\
\hline $\mathrm{PO}_{4}$ & $47.0 \pm 3.7$ \\
\hline \multicolumn{2}{|l|}{$\mathrm{N}$} \\
\hline $\mathrm{NH}_{4}$ & $1525.0 \pm 95.9$ \\
\hline $\mathrm{PO}_{4}$ & $44.7 \pm 2.7$ \\
\hline \multicolumn{2}{|l|}{$\mathrm{P}$} \\
\hline $\mathrm{NH}_{4}$ & $253.2 \pm 4.7$ \\
\hline $\mathrm{PO}_{4}$ & $209.2 \pm 13.1$ \\
\hline \multicolumn{2}{|l|}{$\mathrm{N}+\mathrm{P}$} \\
\hline $\mathrm{NH}_{4}$ & $1388.2 \pm 27.0$ \\
\hline $\mathrm{PO}_{4}$ & $195.7 \pm 11.2$ \\
\hline
\end{tabular}

\section{Experimental design}

The effects of sediment fertilisation, season and species on root morphology and overall architecture were studied in an in situ pot experiment using nutrients (4 levels), season (2 levels) and species (2 levels) as fixed factors. In March (austral autumn) and October (austral spring) 2006, plastic pots (350 × $120 \times 120 \mathrm{~mm}, 3$ vertical slits per side) were assigned randomly to treatments and positioned by SCUBA divers in a $25 \mathrm{~m}^{2}$ subtidal area. Pot preparation and placement followed methods described by Hovey et al. (2011). Treatments had either (1) $10 \mathrm{~g}$ of pot sediment $($ control $=$ no added nutrients), $(2)$ nitrogen $(\mathrm{N})$, $9 \mathrm{~g}$ (equivalent to $88 \mathrm{~g} \mathrm{~N} \mathrm{~m}^{-2}$ ) Osmocote ${ }^{\circledR} 5 \mathrm{mo}$ release, 33\% $\mathrm{N}$ as urea, (3) phosphorus (P), $6 \mathrm{~g}$ (equivalent to $23 \mathrm{~g} \mathrm{P} \mathrm{m}^{-2}$ ) Osmocote ${ }^{\circledR} 5$ mo release, $18 \% \mathrm{P}$ as mono-calcium phosphate or (4) combined $\mathrm{N}+\mathrm{P}, 9 \mathrm{~g}$ of $\mathrm{N}$ and $6 \mathrm{~g}$ of $\mathrm{P}$. All treatments were exposed to ambient nutrient conditions in the water column and sediment porewater, and concentrations of $\mathrm{NH}_{4}$ and $\mathrm{PO}_{4}$ within pots were sampled for each treatment (Table 1; Hovey et al. 2011).
Posidonia australis and P. sinuosa plants were collected from subtidal (1 to $2 \mathrm{~m}$ ) meadows near the experimental plot in March (austral autumn, winter experimental period) and October (austral spring, summer experimental period) 2006. Transplant units consisted of 2 shoots and a length of horizontal rhizome (100 mm for $P$. australis and $70 \mathrm{~mm}$ for $P$. sinuosa), and roots were removed from rhizomes using a razor blade (Hovey et al. 2011). One transplant was planted per pot and anchored with a $150 \mathrm{~mm}$ long plasticcoated wire peg. Transplants were then harvested 6 mo after planting, giving an autumn to winter (winter) and spring to summer (summer) growth period.

Whole root systems were analysed using root and rhizome measuring software (WinRHIZO, Regents Instruments; Bouma et al. 2000). The fresh roots of each transplant were floated in deionised water in a Perspex tray, carefully spread out and then scanned. Primary roots were the main roots attached to the rhizome, and lateral roots were roots branching from primary roots, including first-, second- and third-order branches. These higher orders of branching were not measured separately, as their root diameters were too similar for WinRHIZO to discriminate between the different orders. Parameters measured from the scanned image of the roots included total, primary and lateral root lengths, root surface area and number of branches. After excluding the small growing roots, the topological index (TI) of remaining roots on each plant was estimated by dividing the natural logarithm of the altitude (i.e. maximum number of segments between root tip and root base) by the natural logarithm of the magnitude (i.e. overall number of root tips). A TI close to 1 indicates herringbone root architecture, and TI close to 0 indicates dichotomous root architecture (Fitter 1987, 1991, Fitter \& Strickland 1991).

\section{Statistical analysis}

A 3-way, fixed-factor analysis of variance (ANOVA; SAS v9.0; general linear model) was used to examine direct and interactive effects of species (Sp: Posidonia australis and P. sinuosa), season (S: autumn to winter and spring to summer) and nutrient treatments (Nu: N, P, NP and control). Following a significant main effect or interaction, a Fisher's LSD post hoc test was used to identify significant differences in treatment means. Prior to analysis, data were tested for homogeneity of variance using the Shapiro-Wilks test, and data were transformed where necessary to meet the assumptions of homogeneity of variances (Underwood 1997). 


\section{RESULTS}

Root architecture for both species was significantly altered by the combined addition of $\mathrm{N}$ and $\mathrm{P}$ but not by separate additions. Lateral root density increased (branches $\mathrm{m}^{-1}$ root) in plants with $\mathrm{N}$ and $\mathrm{P}$ addition (Fig. 1A), resulting in a more complex branching pattern that was reflected in the lower TI of the root compartment (Fig. 1B). Root morphology, including root length, root surface area and SRL, was not significantly affected by $\mathrm{N}$ or $\mathrm{P}$ additions (Table 2 ), and was highly variable among nutrient treatments. Shoot to root biomass ratios were also highly variable and showed no significant treatment effects (Fig. 2).

Root architecture was more complex in summer than in winter for both species. In summer there were more higher-order laterals (TI: $0.73 \pm 0.02 \mathrm{SE}$ ) and dichotomous branching, whereas in winter there were fewer laterals, resulting in a typical herringbone structure (TI: $0.86 \pm 0.01$ ). There were also significant differences in root morphology between winter and summer (Table 2), but only in Posidonia australis transplants. Root length in summer-grown $P$. australis transplants was twice that of those grown in winter, whereas root length in $P$. sinuosa transplants showed no significant difference between summer and winter growing periods (Table 3). Shoot to root ratios showed that roots contribute more to the overall biomass in summer than winter for both species (Fig. 2). The increase in $P$. australis root length in summer was mostly due to an increase in average lateral root length, which was $12.90 \pm 0.72 \mathrm{~mm}$ in winter and $20.76 \pm 0.96 \mathrm{~mm}$ in summer. SRL was higher in summer compared to winter, while the opposite was true for mean root diameter, and this seasonal difference was more pronounced in $P$. australis (Table 3), reflecting a seasonal response in lateral root length.
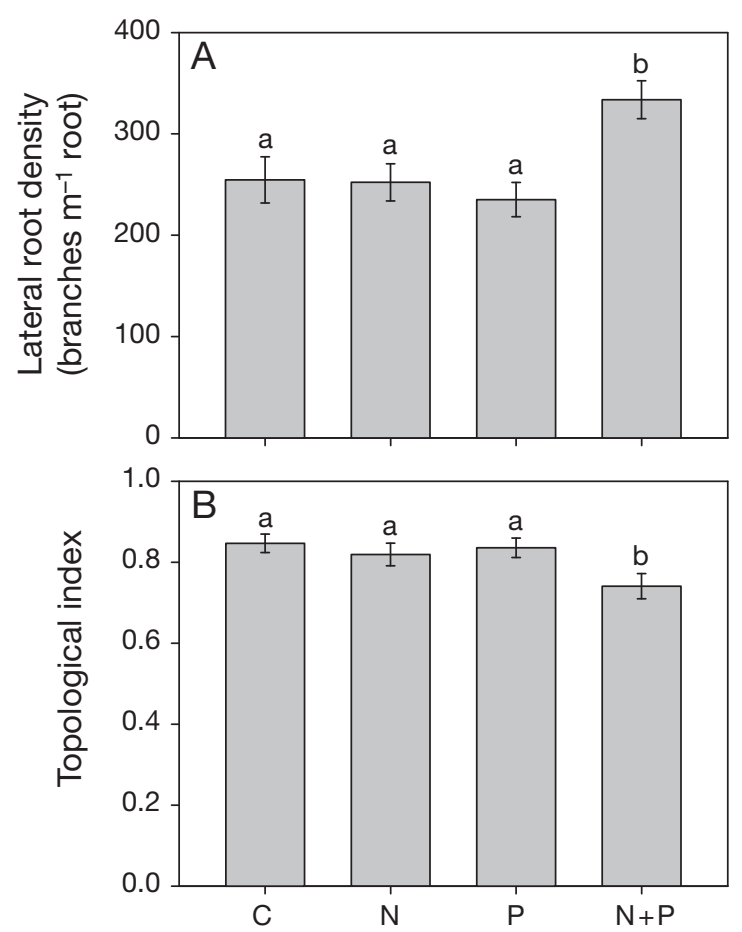

Fig. 1. Posidonia australis and P. sinuosa. (A) Response in lateral root density, a measure of root proliferation, of transplants to nutrient addition (means $\pm \mathrm{SE}, \mathrm{n}=64$ ). (B) The root topological index for transplants growing in pots with either no added nutrients $(\mathrm{C})$, nitrogen $(\mathrm{N})$, phosphorus $(\mathrm{P})$, or combined nitrogen and phosphorus $(\mathrm{N}+\mathrm{P})$ (means $\pm \mathrm{SE}, \mathrm{n}=$ 42 for $\mathrm{C}$ and $\mathrm{N}, \mathrm{n}=43$ for $\mathrm{P}$, and $\mathrm{n}=49$ for $\mathrm{N}+\mathrm{P}$ ). Columns with similar letters are not significantly different $(\mathrm{p}>0.05)$

Root morphology differed between Posidonia species. $P$. australis produced a larger root system overall, a result of both longer primary and lateral roots (Table 3 ). Roots were found to extend in the sediment to depths of 400 and $250 \mathrm{~mm}$ for $P$. australis and $P$. sinuosa, respectively. Average primary root lengths were between 190 and $195 \mathrm{~mm}$ for $P$. australis and

Table 2. Posidonia australis and P. sinuosa. Mean squares from the 3-way ANOVAs on root architecture and morphology measures from transplants with nutrient additions during summer and winter experimental periods. Significant differences at ${ }^{*} \mathrm{p}<0.05,{ }^{* *} \mathrm{p}<0.01$

\begin{tabular}{|c|c|c|c|c|c|c|c|c|}
\hline $\begin{array}{l}\text { Source of } \\
\text { variation }\end{array}$ & df & $\begin{array}{l}\text { Root } \\
\text { length }\end{array}$ & $\begin{array}{c}\text { Root surface } \\
\text { area }^{b}\end{array}$ & $\begin{array}{l}\text { Mean root } \\
\text { diameter }^{b}\end{array}$ & $\begin{array}{l}\text { Lateral root } \\
\text { density }^{\mathrm{a}}\end{array}$ & $\begin{array}{l}\text { Specific root } \\
\text { length }^{b}\end{array}$ & $\begin{array}{l}\text { Topological } \\
\text { index }\end{array}$ & $\begin{array}{l}\text { Shoot to } \\
\text { root ratio }\end{array}$ \\
\hline Species (Sp) & 1 & $4.0560^{* *}$ & $0.0163^{* *}$ & $0.0950^{* *}$ & $0.3880^{* *}$ & $3.6859^{* *}$ & 0.0216 & $52.335^{*}$ \\
\hline Season (S) & 1 & $0.3820^{*}$ & 0.0001 & $0.2610^{* *}$ & 0.0099 & $20.909^{* *}$ & $0.7460^{* *}$ & $323.84^{* *}$ \\
\hline Nutrient $(\mathrm{Nu})$ & 3 & 0.0530 & 0.0000 & 0.0003 & $0.0676^{* *}$ & 0.1391 & $0.0974^{*}$ & 53.766 \\
\hline $\mathrm{Sp} \times \mathrm{S}$ & 1 & $0.4520^{*}$ & $0.0011^{*}$ & $0.0691^{*}$ & 0.0415 & $2.5568^{*}$ & 0.0315 & 24.353 \\
\hline $\mathrm{Sp} \times \mathrm{Nu}$ & 3 & 0.0586 & 0.0002 & 0.0075 & 0.0153 & 0.3029 & 0.0311 & 52.530 \\
\hline $\mathrm{S} \times \mathrm{Nu}$ & 3 & 0.0120 & 0.0001 & 0.0008 & 0.0013 & 0.7465 & 0.0186 & 32.138 \\
\hline $\mathrm{Sp} \times \mathrm{S} \times \mathrm{Nu}$ & 3 & 0.0553 & 0.0002 & 0.0053 & 0.0080 & 0.2416 & 0.0257 & 56.245 \\
\hline
\end{tabular}




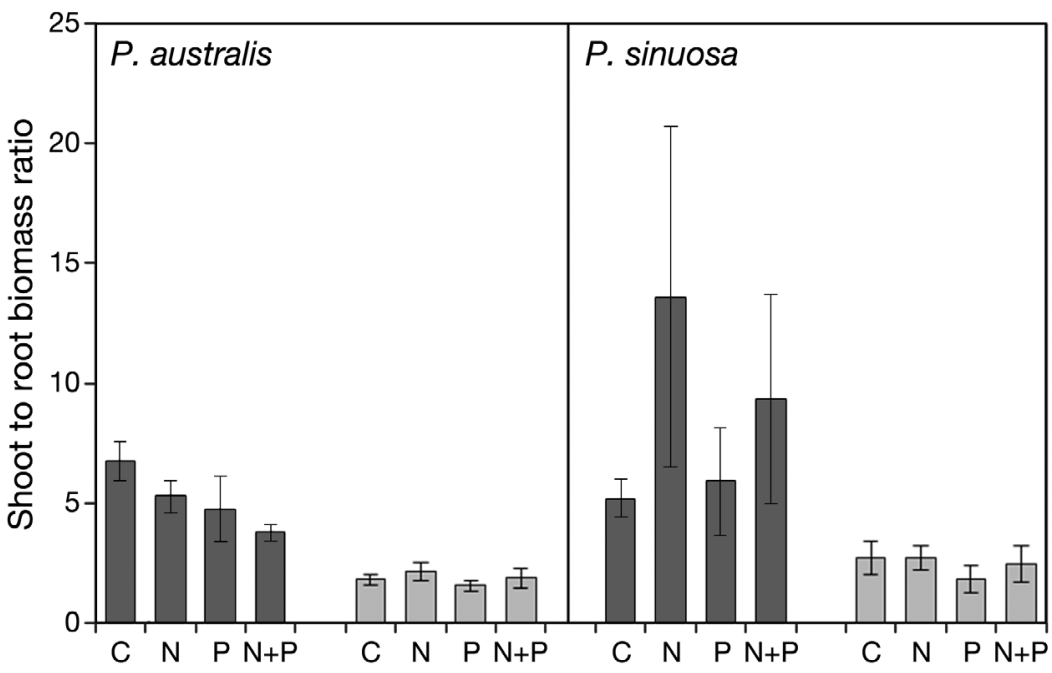

Fig. 2. Posidonia australis and P. sinuosa. Shoot to root biomass ratios of transplants in nutrient treatments for winter (dark grey) and summer (light grey) growth periods (mean $\pm \mathrm{SE}$ ). Ratios were higher in winter than summer $(\mathrm{p}<0.05)$, with no significant treatment effects
140 and $153 \mathrm{~mm}$ for $P$. sinuosa. The root system of both species was predominantly lateral roots (Table 3 ), with the proportion of lateral root to total root length increasing from $71 \pm 3.25 \%$ in winter to $90 \pm 0.86 \%$ in summer for $P$. australis transplants and $59 \pm 3.10 \%$ in winter to $73 \pm 2.96 \%$ in summer for $P$. sinuosa transplants. When compared with Fitter's (1991) root branching patterns, most root systems of the Posidonia transplants fit intermediate branching patterns, as they contained a main axis with a number of firstand second-order laterals (Fig. 3A,B). However, herringbone and dichotomous patterns were also evident (Fig. 3C,D), and could occur on the same transplant. Root hairs were not observed in either species.

Table 3. Posidonia australis and P. sinuosa. Root morphological responses to nutrient additions with species $\times$ season interactions. Mean values $( \pm \mathrm{SE})$ are shown with different superscript letters denoting significant differences in root morphology between $P$. australis and $P$. sinuosa transplants for winter and summer $(\mathrm{p}<0.05)$. SRL: specific root length, Prop. length: proportion of lateral root length per total root length (or root compartment) per plant

\begin{tabular}{|lccccccc|}
\hline & $\begin{array}{c}\text { Total length } \\
(\mathrm{m})\end{array}$ & $\begin{array}{c}\text { Surface area } \\
\left(\mathrm{m}^{2}\right)\end{array}$ & $\begin{array}{c}\text { Primary root } \\
\text { length }(\mathrm{mm})\end{array}$ & $\begin{array}{c}\text { Lateral root } \\
\text { length }(\mathrm{mm})\end{array}$ & $\begin{array}{c}\text { Root diameter } \\
(\mathrm{mm})\end{array}$ & $\begin{array}{c}\text { SRL } \\
\left(\mathrm{m} \mathrm{g}^{-1}\right)\end{array}$ & $\begin{array}{c}\text { Prop. length } \\
(\%)\end{array}$ \\
\hline $\begin{array}{l}\text { P. australis } \\
\text { Winter }\end{array}$ & $2.49 \pm 0.35^{\mathrm{a}}$ & $0.006 \pm 0.0005^{\mathrm{a}}$ & $195.62 \pm 11.43^{\mathrm{a}}$ & $12.90 \pm 0.72^{\mathrm{a}}$ & $0.77 \pm 0.04^{\mathrm{a}}$ & $13.50 \pm 1.24^{\mathrm{a}}$ & $71 \pm 3.25^{\mathrm{a}}$ \\
Summer & $5.03 \pm 0.60^{\mathrm{b}}$ & $0.008 \pm 0.0009^{\mathrm{b}}$ & $190.68 \pm 8.46^{\mathrm{a}}$ & $20.76 \pm 0.96^{\mathrm{b}}$ & $0.51 \pm 0.01^{\mathrm{b}}$ & $27.22 \pm 1.55^{\mathrm{b}}$ & $90 \pm 0.86^{\mathrm{b}}$ \\
$P$. sinuosa & & & & & & & \\
Winter & $0.94 \pm 0.12^{\mathrm{c}}$ & $0.002 \pm 0.0003^{\mathrm{c}}$ & $152.37 \pm 14.42^{\mathrm{b}}$ & $12.31 \pm 1.01^{\mathrm{a}}$ & $0.84 \pm 0.03^{\mathrm{a}}$ & $12.70 \pm 0.89^{\mathrm{a}}$ & $59 \pm 3.10^{\mathrm{c}}$ \\
Summer & $1.03 \pm 0.17^{\mathrm{c}}$ & $0.003 \pm 0.0002^{\mathrm{c}}$ & $139.73 \pm 15.21^{\mathrm{b}}$ & $15.23 \pm 1.44^{\mathrm{a}}$ & $0.78 \pm 0.04^{\mathrm{a}}$ & $18.76 \pm 1.34^{\mathrm{c}}$ & $73 \pm 2.96^{\mathrm{a}}$ \\
\hline
\end{tabular}

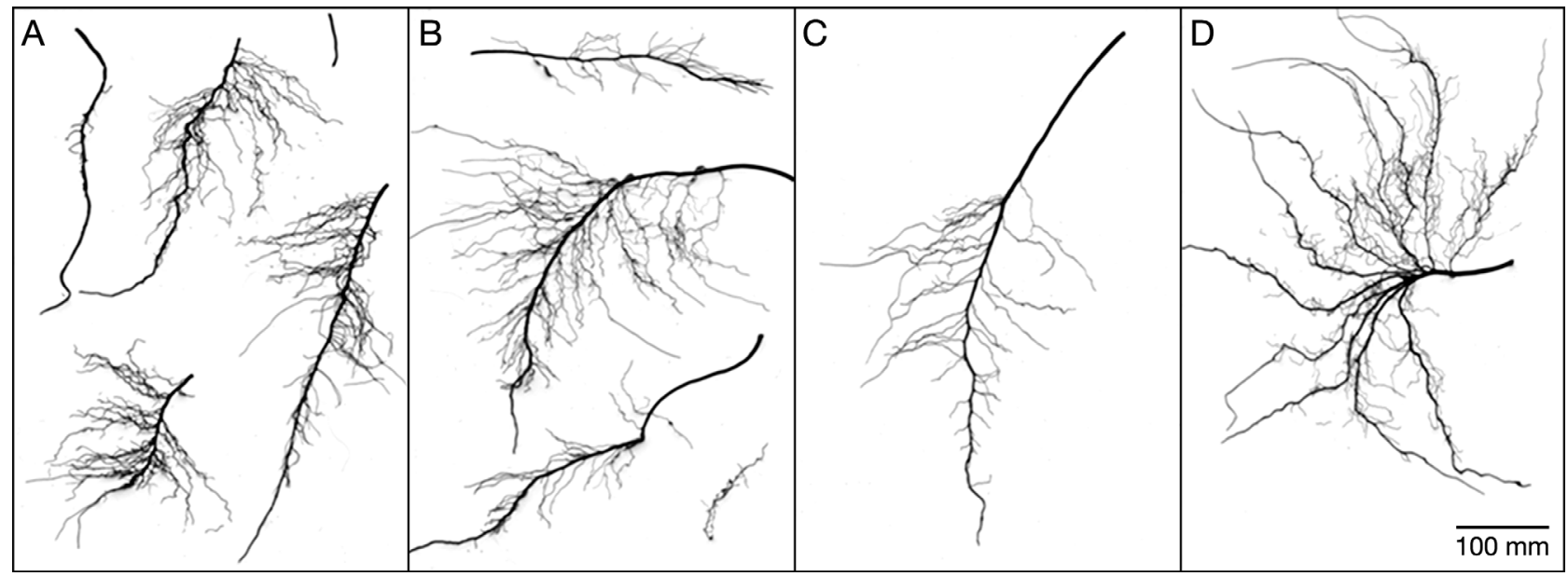

Fig. 3. Posidonia australis. Scanned images of roots showing transplants with (A and B) intermediate root architecture (mix of herringbone and highly branched roots with both secondary and tertiary branching), (C) maximal herringbone architecture,

(D) maximal dichotomous architecture (a highly branching root with secondary, tertiary and quaternary branching) 


\section{DISCUSSION}

This study demonstrates that seagrasses show architectural and morphological plasticity in their root compartment, determined by exposing developing roots of transplants to ambient nutrient conditions and nutrient-rich patches of $\mathrm{N}, \mathrm{P}$ or $\mathrm{N}+\mathrm{P}$, and by studying seasonal growth patterns (autumn to winter and spring to summer). It was clear that nutrient additions tended to affect only the branching patterns of the root compartment, whereas both branching and the overall root length were seasonally influenced. In addition, there were differences in the morphology of the root compartment between the 2 Posidonia species studied, regardless of nutrient supply and growing season, suggesting interspecific differences rather than a general response typical of seagrass roots.

The change in branching patterns of Posidonia australis and $P$. sinuosa roots with nutrient addition is consistent with the prediction that root architecture would shift towards a dichotomous branching pattern with increased nitrogen and phosphorus availability (Fitter \& Stickland 1991). Fitter \& Stickland's (1991) predictions were only substantiated for dicots, as the few grasses studied appeared relatively invariant to nutrient availability (Taub \& Goldberg 1996). However, localised root proliferation has been reported for some monocots when exposed to patchy nutrient supply (Drew 1975, Arrendondo \& Johnson 1999, Johnson \& Biondini 2001). Typically, nutrientrich patches stimulate the formation and elongation of thinner lateral roots that are better suited to exploiting localised nutrient sources (Charlton 1996) and enhance nutrient uptake per unit root mass at a lower cost to the plant (Fitter \& Stickland 1991). However, $P$. australis and $P$. sinuosa did not show any consistent response in the morphology of the root system with the addition of nutrients (total root length, proportion of lateral to primary root length, mean root diameter, surface area, SRL), indicating that nutrient patches did not stimulate elongation of laterals. Water-saturated sediments may also increase the mobility of nutrients, resulting in shorter residence times of localised nutrient sources, leading to a more homogeneous nutrient supply throughout the sediment (Huettel \& Gust 1992, Bouma et al. 2001). A similar lack of response in morphological properties of root systems has been documented in other plants that grow in water-saturated sediments, suggesting that aquatic plants are conservative and that roots do not respond quickly to locally available nutrients (Bouma et al. 2001, Jansen et al. 2005).
We consider that the marginal responses to nutrient additions were genuine 'non-responses' and not the result of ineffective experimental technique. Porewater concentrations taken from inside the pots showed that nutrients were released from Osmocote fertiliser with concentrations up to 5 times higher than controls at ambient nutrient levels (Table 1). Nutrient concentrations in leaves and rhizomes were also higher when $\mathrm{N}$ or $\mathrm{P}$ was added, evidence that plants were taking up the nutrients (see Hovey et al. 2011 for plant nutrient concentrations). No significant change in shoot to root ratio was detected, but it was highly variable (Fig. 2), suggesting that other factors affecting aboveground biomass may be confounding clear responses to nutrient additions. This is supported by Hovey et al. (2011), who demonstrated decreased root productivity with $\mathrm{N}$ additions in summer, which is a typical response when nutrients in the sediment are at adequate to saturating levels (Short 1987).

Differences in root morphology between summer and winter, particularly for Posidonia australis, suggest a seasonal cycle in nutrient demand that may be linked to higher photosynthetic activity and growth of seagrasses in summer. $P$. australis transplants increased root length, lateral root density and overall root fineness from winter to summer, thus increasing total absorptive area of the root system. Therefore, the root system produced in summer had a much higher capacity to take up nutrients. This corresponds to increased nutrient demand associated with rapid shoot growth, which starts early spring and continues through to mid-autumn in temperate seagrasses (Walker \& McComb 1988, Marbà et al. 1996, Guidetti et al. 2002). In addition, a larger root system can be better supported in summer as the increased light availability increases photosynthesis, which is a major source of oxygen for root respiration, and this in turn has a positive effect on the rhizosphere (Hemminga 1998). More oxygen release into the rhizosphere reduces sediment sulphide, a phytotoxin to seagrass (Hemminga 1998, Holmer et al. 2005). Nutrient uptake rates can also be limited by the occurrence of anoxia or hypoxia in the roots that restricts the formation of energy required for ion absorption (Larcher 1995). Thus the balance between rate of photosynthesis and respiration as well as the nutrient demand of the plant, which are all influenced by seasonal variation in light and temperature, may account for the seasonal responses in root morphology in Posidonia transplants.

The extensive roots of Posidonia australis and $P$. sinuosa exceed anything described for temperate sea- 
grasses (Hovey et al. 2011), and branching patterns shown here were more complex than those described in tropical seagrasses (Kiswara et al. 2009). Differences in root architecture (between species) have been related to plant growth strategies, and according to theory, long-lived and slow-growing species living in nutrient-poor environments should support simple or herringbone branching patterns (Fitter et al. 1991). Tropical seagrasses appear to fit this theory, as the slow-growing species (Thalassia hemprichii and Enhalus acroides) had very simple root architecture with few unbranched roots (Kiswara et al. 2009). In contrast, the long-lived and slow-growing temperate seagrasses in our study show architecture that is not consistent with this theory (Fig. 1).

The more complex root architecture in the slowgrowing temperate Posidonia species may reflect hydrodynamic exposure and the importance for anchorage in the wave-swept environments where these species are found (Carruthers et al. 2007, Di Carlo et al. 2007). While it is understood that initiation and development of lateral roots provide important means of constructing a root system that has a high absorptive capacity within a volume of sediment (Charlton 1996), little is known of the mechanical properties of individual roots and the effect of branching patterns. Stokes et al. (1995) found that spruce roots which were less herringbone-like in ranching pattern had increased anchorage strength. Anchorage may be difficult in marine environments, as sediments are 'slippery' and water movements (wave action or currents) exert considerable drag on plants (Vermaat 2009). The extent of developing stresses and strains is unknown, but nonetheless, the size of the root system, the shape of the roots and the magnitude of development of laterals may all contribute to mechanical stability of such plants.

By returning to the sea from the terrestrial environment, seagrasses eliminated the need to respond to water shortages but increased their potential for nutrient acquisition via the shoots from the overlying water column in addition to root uptake from sediments (Short \& McRoy 1984, Pedersen et al. 1997). Therefore, it would be expected that the ecological significance of seagrass roots differs from terrestrial plants. Our study provides some evidence to support this hypothesis, as root response to localised nutrient supply was subtle and contrasted to predictions for terrestrial dicots and monocots. In addition, evidence of seasonality and interspecific differences in root development suggest that we should be cautious when applying generalised ecological patterns to seagrasses.
Acknowledgements. This study was funded by an Australian Research Council Linkage Grant (LP0454138) to G.A.K., with financial contributions from Cockburn Cement Limited and the Western Australian Department of Industry and Resources. We thank G. Bastyan, J. Statton, R. Hovey, R. Barrett and R. Kendrick for field assistance. Finally, we thank the reviewers whose constructive feedback resulted in an improved manuscript.

\section{LITERATURE CITED}

Agami M, Waisel Y (1986) The ecophysiology of roots of submerged vascular plants. Physiol Veg 24:607-624

> Arrendondo JT, Johnson DA (1999) Root architecture and biomass allocation of three range grasses in response to non-uniform supply of nutrients and shoot defoliation. New Phytol 143:373-385

Balestri E, Lardicci C (2006) Stimulation of root formation in Posidonia oceanica cuttings by application of auxins (NAA and IBA). Mar Biol 149:393-400

Bastyan GR, Cambridge ML (2008) Transplantation as a method for restoring the seagrass Posidonia australis. Estuar Coast Shelf Sci 79:289-299

> Bouma TJ, Nielsen KL, Koutstaal BP (2000) Sample preparation and scanning protocol for computerised analysis of root length and diameter. Plant Soil 218:185-196

> Bouma TJ, Koutstaal BP, van Dongen M, Nielsen KL (2001) Coping with low nutrient availability and inundation: root growth responses of three halophytic grass species from different elevations along a flooding gradient. Oecologia 126:472-481

Bristow JM (1975) The structure and function of roots in aquatic vascular plants. In: Torrey JG, Clarkson DR (eds) The development and function of roots. Academic Press, New York, NY, p 221-233

- Cambridge ML, Kendrick GA (2009) Contrasting responses of seagrass transplants (Posidonia australis) to nitrogen, phosphorus and iron addition in an estuary and a coastal embayment. J Exp Mar Biol Ecol 371:34-41

Carruthers TJB, Dennison WC, Kendrick GA, Waycott M, Walker DI, Cambridge ML (2007) Seagrasses of southwest Australia: A conceptual synthesis of the world's most diverse and extensive seagrass meadows. J Exp Mar Biol Ecol 350:21-45

Charlton WA (1996) Lateral root initiation. In: Waisel Y, Eshel A, Kafkafi U (eds) Plant roots: the hidden half. Marcel Dekker, New York, NY, p 149-173

Di Carlo G, Badalamenti F, Terlizzi A (2007) Recruitment of Posidonia oceanica on rubble mounds: substratum effects on biomass partitioning and leaf morphology. Aquat Bot 87:97-103

$>$ Drew MC (1975) Comparison of the effects of a localised supply of phosphate, nitrate, ammonium and potassium on the growth of the seminal root system, and the shoot, in barley. New Phytol 75:479-490

Evrard V, Kiswara W, Bouma TJ, Middelburg JJ (2005) Nutrient dynamics of seagrass ecosystems: ${ }^{15} \mathrm{~N}$ evidence for the importance of particulate organic matter and root systems. Mar Ecol Prog Ser 295:49-55

> Duarte CM (1991) Seagrass depth limits. Aquat Bot 40: 363-377

> Fitter AH (1987) An architectural approach to comparative ecology of plant root systems. New Phytol 106:61-77

Fitter AH (1991) The ecological significance of root system 
architecture: an economic approach. In: Atkinson D (ed) Plant root growth: an ecological perspective. Blackwell Scientific Publishers, London, p 229-243

Fitter AH, Stickland TR (1991) Architectural analysis of plant root systems. 2. Influence of nutrient supply on architecture in contrasting plant species. New Phytol 118:383-389

> Fitter AH, Stickland TR, Harvey ML, Wilson GW (1991) Architectural analysis of plant root systems. 1. Architectural correlates of exploitation efficiency. New Phytol 118:375-382

Guidetti P, Lorenti M, Buia MC, Mazzella L (2002) Temporal dynamics and biomass partitioning in three Adriatic seagrass species: Posidonia oceanica, Cymodocea nodosa, Zostera marina. PSZN I: Mar Ecol 23:51-67

Hemminga MA (1998) The root/rhizome system of seagrasses: an asset and a burden. J Sea Res 39:183-196

Hodge A (2004) The plastic plant: root responses to heterogeneous supplies of nutrients. New Phytol 162:9-24

> Holmer M, Frederiksen MS, Mollegaard H (2005) Sulfur accumulation in eelgrass (Zostera marina) and effect of sulfur on eelgrass growth. Aquat Bot 81:367-379

> Hovey RK, Cambridge ML, Kendrick GA (2011) Direct measurements of root growth and productivity in the seagrasses Posidonia australis and P. sinuosa. Limnol Oceanogr 56:394-402

> Huettel M, Gust G (1992) Impact of bioroughness on interfacial solute exchange in permeable sediments. Mar Ecol Prog Ser 89:253-267

Jansen C, Van De Steeg HM, De Kroon H (2005) Investigating a trade-off in root morphological responses to a heterogeneous nutrient supply and to flooding. Funct Ecol 19:952-960

Johnson HA, Biondini ME (2001) Root morphological plasticity and nitrogen uptake of 59 plant species from the Great Plains grasslands, USA. Basic Appl Ecol 2: 127-143

Kilminster KL, Walker DI, Thompson PA, Raven JA (2006) Limited nutritional benefit to the seagrass Halophila ovalis, in culture, following sediment organic matter enrichment. Estuar Coast Shelf Sci 68:675-685

Kiswara W, Behnke N, van Avesaath P, Huiskes AHL, Erftemeijer PLA, Bouma TJ (2009) Root architecture of six tropical seagrass species, growing in three contrasting habitats in Indonesian waters. Aquat Bot 90: 235-245

Larcher W (1995) Physiological plant ecology. Springer, Berlin

Editorial responsibility: Just Cebrian,

Dauphin Island, Alabama, USA
Lynch J (1995) Root architecture and plant productivity. Plant Physiol 109:7-13

- Marbà N, Cebriàn J, Enríquez S, Duarte CM (1996) Growth patterns of western Mediterranean seagrasses: speciesspecific responses to seasonal forcing. Mar Ecol Prog Ser 133:203-215

> Marbà N, Duarte CM (2001) Growth and sediment space occupation by seagrass Cymodocea nodosa roots. Mar Ecol Prog Ser 224:291-298

> Pedersen MF, Paling EI, Walker DI (1997) Nitrogen uptake and allocation in the seagrass Amphibolis antarctica. Aquat Bot 56:105-117

Perez M, Duarte CM, Romero J, Sand-Jensen K, Alcoverro T (1994) Growth plasticity in Cymodocea nodosa stands: the importance of nutrient supply. Aquat Bot 47:249-264

Robinson D (1994) The responses of plants to non-uniform supplies of nutrients. New Phytol 127:635-674

Short FT (1987) Effects of sediment nutrients on seagrasses: literature review and mesocosm experiment. Aquat Bot 27:41-57

Short FT, McRoy CP (1984) Nitrogen uptake by leaves and roots of the seagrass Zostera marina L. Bot Mar 27: $547-555$

Stokes A, Fitter AH, Courts MP (1995) Responses of young trees to wind and shading: effects on root architecture. J Exp Bot 46:1139-1146

> Taub DR, Goldberg D (1996) Root system topology of plants from habitats differing in soil resource availability. Funct Ecol 10:258-264

Underwood AJ (1997) Experiments in ecology: their ecological design and interpretation using analysis of variance. Cambridge University Press, Cambridge

> Vermaat JE (2009) Linking clonal growth patterns and ecophysiology allows the prediction of meadow-scale dynamic of seagrass beds. Persp Plant Ecol Evol Syst 11: $137-155$

> Vonk JA, Middelburg JJ, Stapel J, Bouma TJ (2008) Dissolved organic nitrogen uptake by seagrasses. Limnol Oceanogr 53:542-548

> Walker DI, McComb AJ (1988) Seasonal variation in the production biomass and nutrient status of Amphibolis antarctica (Labill.) Sonder ex Aschers. and Posidonia australis Hook. f. in Shark Bay, Western Australia. Aquat Bot 31:259-276

> Yano K, Kume T (2005) Root morphological plasticity for heterogeneous phosphorus supply in Zea mays. Plant Prod Sci 8:427-432

Submitted: February 3, 2011; Accepted: November 7, 2011 Proofs received from author(s): January 30, 2012 